\title{
Sexual behavior and physical aspects of the semen of Moxotó breed goats at different ages
}

\section{Comportamento sexual e aspectos físicos do sêmen caprino da raça Moxotó em diferentes idades}

\author{
Vinícius de França Carvalho Fonsêca ${ }^{1}$; Edílson Paes Saraiva ${ }^{2 *}$ \\ Edgard Cavalcanti Pimenta Filho²; Rinaldo José Souto Maior Júnior'; \\ Walter Esfraim Pereira ${ }^{3}$; Adriano Leite da Silva ${ }^{1}$; \\ Diego Lima da Silva Gomes ${ }^{1}$; José Helder de Andrade Moura ${ }^{1}$
}

\begin{abstract}
This study aimed to evaluate physical aspects of the semen and sexual behavior of Moxoto breed goats at different ages. Two males Moxotó goats, ages 4 and 7, represented by (1) and (2) respectively, and twenty-six (26) female goats as mannequins, were used. The breeders were subjected to sexual behavior evaluation by measuring of reaction time to the female in estrus, which were recorded the patterns of behavior (courtship with paw, emission of sounds, tongue exposure, exposure penis exposure, smell the urogenital female and Flehmen reflex) performed in two shifts (morning and afternoon) during the months of February to April 2010, totaling 50 observations. To assess the physical aspects of semen collections were performed twice on each breeder at the beginning and end of the observation period. There was no difference in reaction time and the number of jumps in terms of shifts and breeders. The frequency of behavioral events in relation to shifts evaluation did not differ. The emission of sounds (EMS) and exposure of the tongue (EXL) was expressed more often by the oldest breeder (2). Regarding the assessment soundness, the average values for the parameters studied as motility, vigor, pathology and sperm concentration, results were favorable to the breeder (1). The study of behavioral patterns during the courting stage is an indispensable tool in predicting the reproductive potential of male goats; however, other aspects within the reproductive management should be evaluated in combination.
\end{abstract}

Key words: Behaviours events, ethology, reaction time

\section{Resumo}

Este estudo objetivou avaliar o comportamento sexual e aspectos físicos do sêmen de reprodutores caprinos da raça Moxotó. Foram utilizados dois reprodutores, com idades de 4 e 7 anos, representados por (1) e (2), respectivamente, e vinte e seis (26) cabras como manequins. Os reprodutores foram submetidos à avaliação do comportamento sexual pela medida do tempo de reação frente à fêmea em estro, onde foram registrados os padrões de comportamento (cortejo com a pata, emissão de sons, exposição da língua, exposição do pênis, cheirar a região urogenital da fêmea e reflexo de flehmen) realizados em dois turnos (manhã e tarde) durante os meses de fevereiro à abril de 2010, totalizando

\footnotetext{
1 Discente(s) do programa de doutorado integrado em zootecnia, Universidade Federal da Paraíba, PDIZ/UFPB, Areia, PB. E-mail: vinicius_fonseca86@hotmail.com; rinaldosmjunior@hotmail.com; adrianozootecnista@yahoo.com.br; diegolima@ zootecnista.com.br; josehelder_ztc@hotmail.com

2 Profs. Adjunto(s) do Programa de Doutorado Integrado em Zootecnia, PDIZ/UFPB, Areia, PB. E-mail: edilson@cca.ufpb.br; edgard@cca.ufpb.br

3 Prof. do Dept ${ }^{\circ}$ de Ciências Fundamentais e Sociais, DCFS/UFPB, Areia, PB. E-mail: walter@cca.ufpb.br

* Author for correspondence
} 
50 observações. Para avaliação dos aspectos físicos do sêmen, foram realizadas duas coletas em cada reprodutor no início e fim do período de observações. Não houve diferença quanto ao tempo de reação e ao número de saltos em função dos turnos e reprodutores. A freqüência dos eventos comportamentais em relação aos turnos de avaliação não diferiu. A emissão de sons (EMS) e exposição da língua (EXL) foi expresso mais vezes pelo reprodutor mais velho (2). Com relação à avaliação andrológica os valores médios encontrados para os parâmetros estudados como motilidade, vigor, patologia e concentração espermática, apresentaram resultados favoráveis ao reprodutor (1). O estudo dos padrões comportamentais durante a fase de cortejo é uma ferramenta indispensável na predição do potencial reprodutivo de machos caprinos, contudo, outros aspectos dentro do manejo reprodutivo devem ser conjuntamente avaliados.

Palavras-chave: Eventos comportamentais, etologia, tempo de reação

\section{Introduction}

The goat farming in the Northeast over the past few years has undergone major changes in its supply chain; including significant increase in demand for products and derivatives by the market. Given this favorable outlook that goes through the activity, producers need to invest in genetics, technology and management, considering that the semiextensive system is predominant in the region with low zootechnical indexes, especially with regard to reproductive management.

Regardless of the type or rearing system adopted in the property, it must have careful priority attention for reproductive managing, since production is restricted to the level zero in the absence of breeding. Thus, it is essential to identify the best males for use as breeding stock, since the natural breeding scheme is predominant in the goats farming, and they must be able to serve effectively as many females in a short period of time, thereby reducing production costs. Therefore, it becomes relevant to the combined assessment of semen characteristics and sexual behavior as criteria in the males selection before initiating a breeding program.

The attitudes and motor activities practiced by males and females relate to reproductive behavior adopted by them, and such behavior is nothing more than a response to external stimuli which are typically pheromones, chemical substances secreted in the urine, feces or glands that trigger specific responses in individuals of the same species (HAFEZ; HAFEZ, 2004). Thus, it is through the libido and implementation phases of mating behavior that animal sexual behavior is assessed, when the male is faced with one or more females in estrus, manifesting by signs of interest, excitement and copulation (HENRY; NEVES, 1998).

The infertile breeder is rapidly identified, but those with subfertility have serious problems and cause economic losses for farmers and for artificial insemination programs; reinforcing the need for adequate breeder's monitoring in the property. Therefore, the andrological assessment is one of the most frequently used to assess the possible fertility potential of the animal (SALVADOR; ANDRADE; VALE FILHO, 2002).

With regard to sperm production in goats, this may be influenced by factors such as breed, nutrition, photoperiod, environmental temperature and humidity, which are responsible for variation in semen characteristics (CHEMINEAU, 2004). In this context, the analysis of sperm motility and morphology have been identified as important tool in the ejaculate selection, and determining the percentage of motile sperm is the most used test to predict semen quality (VERSTEGEN; IGUEROUADA; ONCLIN, 2002).

Furthermore, the frequency and duration of behaviors and ejaculation vary between adult and experienced males, and this variation among individuals can be used as evaluation criteria, classification and selection of breeders (STELLFLUG; LEWIS, 2007). Therefore, the study of sexual behavior and andrological analysis 
aiming at assessing the true reproductive capacity of the male goat is important tool for breeder selection. Thus, satisfactory results in the herd production indices can be achieved.

The objective of this work was to assess the sexual behavior and physical quantitative aspects in the ejaculate of Moxotó goat breeders under a controlled breeding scheme.

\section{Material and Methods}

The experiment was conducted at the Experimental Station of São João do Cariri, belonging to the Center of Agrarian Sciences, Federal University of Paraíba - CCA / UFPB, located in São João do Cariri - PB. According to Thornthwaite's classification, the climate is semiarid $(-60<\operatorname{Im}<-$ 40 ), with $450 \mathrm{~mm}$ average annual rainfall, $7^{\circ} 25^{\prime} \mathrm{S}$ latitude and $36^{\circ} 30^{\prime} \mathrm{W}$ longitude, 450 to $500 \mathrm{~m}$ average altitude, $26^{\circ} \mathrm{C}$ average annual temperature and $63 \%$ average air relative humidity.

Animals were distributed in a completely randomized design and $2 \times 2$ factorial arrangement ( 2 ages and 2 shifts). Were used two male Moxotó goats, belong to the Experimental Station of São João do Cariri with aged between 4 and 7 years. It was characterized as breeder (1) that one aged at about 4 years and as breeder (2) that one aged at about 7 years.

For assessment of sexual behavior were used twenty-six (26) goats as models, which were submitted to estrus synchronization according to recommendations of Traldi (2001) by using $50 \mathrm{mg}$ of synthetic prostaglandin, which led to the estrus emergence about $50 \pm 1$ hours after application. Goats that did not respond to the first treatment received the second dose 11 days after the first one.

The male breeders were housed in conventional paddocks surrounded with smooth wire, with natural shade of mesquite trees (Prosopis juliflora DC) as covering material near the females, which they were installed in individual stalls, with 3.75 $\mathrm{m}^{2}$, made of wood and covered with ceramic tiles. Animals were fed with concentrate based on corn bran, soybean, wheat, cotton, mineral and vitamin premix, in addition to forage diet consisting of Tifton hay (Cynodon spp cv). The diet was provided in complete form in the morning after the observation period.

Behavioural observations were conducted in two shifts (morning and afternoon) during February, March and April 2010, yielding a total of 50 observations throughout the experiment. Every twenty days was made the synchronization at a group of six goats and when found the estrus stage, they were randomly assigned to each of the two breeders, which were taken to their respective female in an individual box performing the behavioral observations. The sexual behavior of breeders was characterized by measuring the reaction time (time between the goat release to mating and the first ejaculation) and the registration of the number of jumps (No. \ST). The frequency in the occurrence of behavioral events was also recorded during the reaction time continuously. The reaction time measurements were taken using a digital chronometer, while the frequency of behavioral variables was quantified by specific individual sheets by trained observers on a relative distance, so that not interfering with the animal's behavior.

Two samplings of semen were performed in each breeder, one at the beginning and the other in end of breeding season in order to comply with the cycle of 51 days for spermatogenic process for purposes of evaluating the semen physical aspects. The ejaculates of two breeders were collected late afternoon by artificial vagina method with water heated to 42 degrees Celsius. The following seminal characteristics were analyzed according to recommendations of the Brazilian College of Animal Reproduction (HENRY; NEVES, 1998): 1-Volume (VOL), measured immediately after collection, directly into the graduated tube, expressed in milliliters; 2 - Aspect (ASP) 1-4 scale, ranging from 
watery to creamy, 3 - Progressive Motility (MOT), subjective evaluation of a semen aliquot (20 il), placed between slide and coverslip previously heated at $37^{\circ} \mathrm{C}$ and visualized by bright field optical microscopy 92 and 100- magnification. It shows the sperm percentage with progressive straight movements, 4- Vigor (VIG), subjective evaluation, expressing the speed at which the sperm moves into the field. The result was expressed on a scale $0-5,0$ being no motion and 5 intense speed, 6 - whirling or mass moving (TURB), determined by assessing a semen drop placed on a slide previously heated to $37^{\circ} \mathrm{C}$ and viewed in bright field optical microscopy and 100- magnification, results expressed on a scale of 0 to 5 , with 0 being no movement and 5 intense movement; 7 - sperm concentration (CONC) obtained by counting the number of sperm previously diluted in citrate buffered formalin solution at 1:200 in a Neubauer chamber, results expressed as million sperm per milliliter. Some of the analyzes were performed immediately after collections in their own experimental station, while other semen parameters were measured in the laboratory of semen technology belonging to the Department of Veterinary Medicine at Rural Federal University of Pernambuco (DMV / UFRPE).

Forty days after the end of the breeding season, all the experimental goats were subjected to pregnancy diagnosis using transrectal ultrasound, which the reproductive performance of both breeders was assessed comparatively by pregnant females number, correlating or not with physical characteristics of the sperm of each of the breeders.

For frequency analysis of behavioral patterns, reaction time and number of jumps, a generalized linear models (Deviance analysis), considering the Poisson distribution, were used. The results when significant were compared by chi-square test at $1 \%$ probability. In the andrological assessment was obtained the average values for both samplings. All statistical analyzes were performed using the SAS (1999).

\section{Results and Discussion}

There was no interaction between factors (breeder x shift) for reaction time, number of jumps and frequency of behaviors assessed, so that each factor will be discussed separately.

The time required for male to mate a female in estrus after being taken to a breeding ground is called the reaction period (MELVIN; SWENSON; WILLIAM, 1996). The two animals' performance on the reaction time $(\mathrm{RT})$ did not differ $(\mathrm{P}>0.01)$ despite the breeder having showed a numerically lower mean (Table 1). Older animals, such as the breeder 2 , seem to require higher stimuli during the phase prior to the mating. In the present study these results can be attributed to the fact that, despite the difference in animals' age and taking this aspect into account, both are mature and sexually experienced, since breeding goats reach sexual maturity at 12 months of age (HAFEZ; HAFEZ, 2004).

Table 1. Mean reaction time (RT) and number of jumps (Jumps $\mathrm{N}^{\circ}$ ) depending on breeders and observation shifts.

\begin{tabular}{|c|c|c|c|}
\hline \multirow{2}{*}{ Variables } & \multicolumn{2}{|c|}{ Variation sources } & \multirow{2}{*}{ Chi-Square } \\
\hline & Breeder 1 & Breeder 2 & \\
\hline TR (s) & 88.80 & 104.80 & 0.17 \\
\hline Jumps $\mathrm{N}^{\mathrm{o}}$ & 2.47 & 2.47 & 0.69 \\
\hline & Morning & Afternoon & \\
\hline TR (s) & 85.34 & 108.86 & 0.93 \\
\hline Jumps $\mathrm{N}^{\mathrm{o}}$ & 2.33 & 2.13 & 0.07 \\
\hline
\end{tabular}

Means followed by different letters in the row differ among each other $(\mathrm{P}<0.01)$ by the chi-square test. Breeder 1: aged at about 4 years; Breeder 2: aged at about 7 years.

Source: Elaboration of the authors. 
In studies with exotic goats of different ages (4 to 5 years and 13 months), Santos, Torres and Fonseca (2006) found a shorter reaction time compared to this experiment and also age differences, in which young animals had the lowest means for this variable. It can be inferred that due to the higher avidity of younger and less experienced animals, they divert more attention to perform the ride than to test the female's receptivity; therefore, less time to erection and copulation is spent.

Assessing the sexual performance in goats of different genotypes, native and exotic, Santos, Alfaro and Souza (2005) found means for Moxotó animals with 12 months of age (117 s) similar to this study for the period of latency to ejaculation. In this study, the authors considered the reaction time as the moment that the animal triggers the first reaction face the female. Researches on the reproductive seasonality depending on age in goats are scarce in the literature, especially considering the aspects related to the animals' libido. Attention should be drawn to the fact that breeders in this study aged 4-7 years obtained similar performance to that of young animals of the same breed, which had just reached sexual maturity. Therefore, it seems that longevity for reproductive activity taking into account the libido expression may be characteristic for Moxotó breeders.

With respect to the shifts of observation, there was no difference $(\mathrm{P}>0.01)$ between the morning and afternoon for the TR. The moment when breeders were subjected to the assessments, both in the morning and afternoon, contemplated the cooler times of the day, which favored the occurrence of similar times between both shifts. The climatic elements vary depending of the schedule, so that the responses for libido expression in male goats are directly influenced and can be damaged in some situations of thermal stress, caused mainly by increased environmental temperature. The ability of males exhibiting sexual behavior under hightemperature conditions may be a characteristic to be selected indirectly to the development of certain breeds in tropical climates (PACHECO; QUIRINO,
2010). In the assessment of sexual behavior in Boer goats, Alves et al. (2006) found that animals reacted faster in the morning observation period, attributing the result to the night rest of the animals.

The number of jumps per observation was not influenced $(\mathrm{P}>0.01)$ by the difference in age of the animals, either by shifts of evaluation (Table 1). The breeders of this experiment achieved average of 2.47 jumps. It means for service capacity the number of females served by a breeder at a given time interval, where the number of jumps for male's attempt direct influence on its prediction. In the case of a system with natural mating, the higher the number of jumps per served female, the greater wear and wasted energy from the breeder and thus, its efficiency can be compromised by lower number of served females. With regard to age, Santos, Torres and Fonseca (2006) also found no influence among young and adult animals on number of jumps per semen collection.

The first expression phase of reproductive behavior is the search and identification of the sexual partner, followed by the verification of the partner ' $\mathrm{s}$ physiological state that can evolve to the reaction and finally copulation (PACHECO; QUIRINO, 2010). During this stage various behavioral events are triggered by the male goat sequentially (Figure 1). Among these events, courting with the paw (CP) represents a form of tactile communication between the breeder and estrous goat and is part of the preparatory phase, when the male is still testing for the female's receptivity and its excitation. In percentage terms the $\mathrm{CP}$ was expressed in relation to other behavioral patterns by breeder 1 in the range of $20.53 \%$ and by the older animal in the range of $15.26 \%$; but there was no difference (P> 0.01 ) among animals under study. Not only for goats, this type of action with the anterior limbs is part of the sequence of events during courtship in the sheep males, evidenced by Goldfrey, Collins and Gray (1998) that assessing the sexual behavior of two sheep breeds found high expression of this action in both genotypes. 
Figure 1. Percentage of behavioral events during the observations.

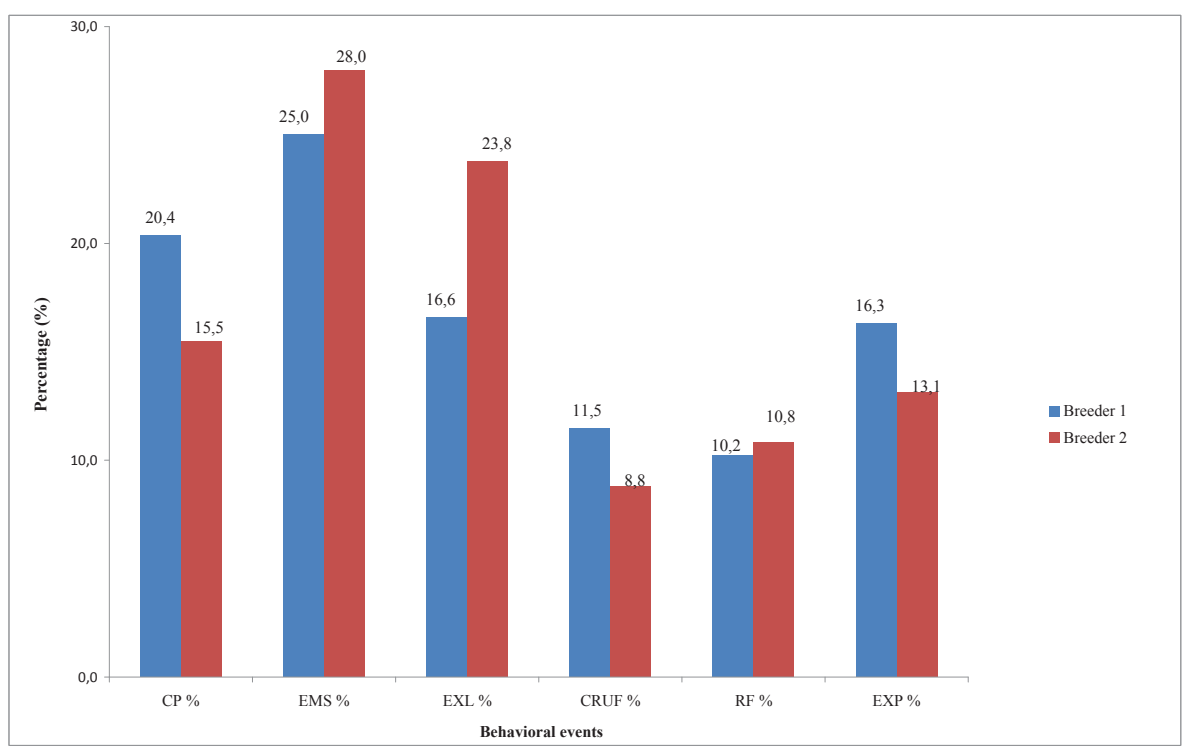

CP: courting with the paw; EMS: sounds emission, EXL: tongue exposure; CRUF: smelling the female's urogenital region; RF: Flehmen reflex; EXP: penis exposure. Breeder 1: aged at about 4 years; Breeder 2: aged at about 7 years.

Source: Elaboration of the authors.

During the preparatory phase, males of some species emit characteristic sounds, which is supposed to be a way to draw the attention of the female being courted. In goats vocalization is evident and as a paradigm, in most cases, some producers associate this feature at the level of animals' libido, ie. the higher the intensity and frequency in the sounds emission, rather reproductive potential is assigned to the breeder. In the present study, the first breeder 1 vocalised at a lower percentage $(25.02 \%)$ compared to the breeder $2(27.96 \%)$ in relation to other events, as well as, the frequency was higher ( $\mathrm{P}<0.01)$ for the older animal (2). The expression of male' sexual behavior is influenced by several factors and the individual characteristics is a major one. Therefore, differences in the intensity of some behavioral events during the preparatory phase should not always be attributed to the age factor. However, McGary, Estevez and Russek-Cohen (2003) observed after studies on young sheeps that they exhibit a behavior named "separation anxiety" with aggressive attitudes and excessive vocalization.

For the animals interact with the environment and express some behavior, they use the senses sight, hearing, smell, touch and taste as tools. Of these, smelling is the primary sense used to trigger the reproductive behavior (GORDON, 1999). In the sequence of behavioral events during courtship, the male's olfactory checking towards the female in estrus, is expressed by the tongue exposure (EXL) and the act of smelling the urogenital region (CRUF), triggering a response in the breeder known as Flehmen reflex (RF). Smelling and licking the female's urine causes the male to perform a ritual known as Flehmen reflex or effect, raising the head and bending the upper lip. Since this is an olfactory investgation controlled by the testosterone action (LADEWIG; PRICE; HART, 1980).

In this study, it was found that among the three variables, only the act of exposing the tongue occurred more frequently $(\mathrm{P}<0.01)$ for breeder 2 , suggesting that older animals use this olfactory trick during the preparatory phase to obtain a better identification of female's receptivity and greater excitement before the stages of erection and copulation. There was no difference $(\mathrm{P}>0.01)$ between breeders with regard to the penis exposure (EXP). The early expression of this behavior occurs 
when the male is already excited and ready to mate, ending the sequence of behavioral patterns with the copulation and ejaculation in the female's reproductive tract.

The expression of olfactory behaviors by the male is directly related to the level of pheromones released by the female. Salviano, Cavalcante and Souza (2006), studying sheeps of different ages, found that the least amount of pheromones released by females out of the estrus led to increased frequency of behaviors of persecution, smelling, licking and Flehmen reflections followed however, by a lower performance in full mating.

During the assessments in different shifts, there was no difference $(\mathrm{P}>0.01)$ in frequency in any of the behavioral variables performed by males under study (Table 2). In driven natural mating system, the timing of mating is a major factor in the mating efficiency, since the failure of gametes fertilization can occur due to extreme situations of environmental temperature. As already explained above, the mating period in this study during the morning and afternoon was performed at the times of warmer temperatures, showing the unchanged patterns of courtship behavior of breeders in question. The increased environmental temperature causes heating of testicles, and consequently increased metabolism and oxygen demand by cells, but its blood flow is limited and becomes unable to meet such demand, resulting in reduced male fertility (KUMAGAI; FUKUDA; KODAMA, 2000).

From the following steps, a careful assessment about the reproductive efficiency of a male goat, the ejaculate quality (Table 3) is crucial in the decision making to select a breeder for a breeding season.

Table 2. Average frequency of behavioral variables in observation shifts.

\begin{tabular}{cccc}
\hline & \multicolumn{2}{c}{ Evaluation Periods } & Chi-Square \\
\cline { 2 - 3 } Variables & Morning & Afternoon & 0.34 \\
CP & 2.66 & 2.58 & 1.51 \\
EMS & 5.05 & 3.66 & 0.67 \\
EXL & 3.14 & 3.10 & 3.15 \\
CRUF & 1.16 & 1.84 & 1.69 \\
RF & 2.00 & 1.45 & 0.24 \\
EXP & 2.28 & 1.95 & 0 \\
\hline
\end{tabular}

CP: courting with the paw; EMS: sounds emission, EXL: tongue exposure; CRUF: smelling the female's urogenital region; RF: Flehmen reflex; EXP: penis exposure. Means followed by different letters in row differ $(\mathrm{P}<0.01)$ by chi-square test at $1 \%$ probability. Source: Elaboration of the authors.

Table 3. Means of andrological variables in both breeders.

\begin{tabular}{lll}
\hline \multirow{2}{*}{ Variable } & \multicolumn{2}{c}{ Mean values } \\
\cline { 2 - 3 } Volume (ml) & Breeder 1 & Breeder 2 \\
\cline { 2 - 3 } Vigor & 0.5 & 1 \\
Total number of sperm (sperm / ml) & 4 & 2 \\
Progressive motility (\%) & $2,5 \times 10^{9}$ & $2 \times 10^{9}$ \\
Pathology (\%) & 80 & 20 \\
Color & 12 & 31.5 \\
Mass movement & Yellow & Yellow \\
\hline
\end{tabular}

Breeder 1: aged at about 4 years; Breeder 2: aged at about 7 years.

Source: Elaboration of the authors. 
The ejaculate volume is very susceptible to the variations, depending on the collection method, animal species, service conditions prior to collection, excitation time, among others (SALVIANO; SOUZA, 2008). Goats semen volume ranges from 0.2 to $2.0 \mathrm{ml}$ with average of $0.8 \mathrm{ml}$ (HENRY; NEVES, 1998). Therefore, average values of both animals evaluated in this study are in the normal standard to the species. With regard to sperm vigor, this represents the force which the sperm move. The ejaculate the breeder 1 showed vigor 4 , while the semen in the older breeder obtained value of 2 , and in this case below the normal recommended for goats. The vigor correlates positively with progressive motility, so that it may be representative regarding the inferences to the semen quality. Under intensive semen collection, Moxotó goats had average of 3.7 for sperm vigor (BRITO et al., 2008).

Regarding the total number of sperm, both animals showed similar media and within the normal for the species. Testicular thermoregulation has important role on sperm concentration, which in situations of heat stress the inefficiency in maintaining the internal temperature of testicles can cause damage to the spermatogenic process and as a consequence, lower sperm concentration. As for progressive motility, the oldest breeder (2) showed a far below percentage than that recommended by the Brazilian College of Animal Reproduction (HENRY; NEVES, 1998) for goats (80\%), value expressed by breeder 1. According to Mies Filho (1987), this is one of the main features that should be taken into account in the semen examination for evaluation of its fertilizing capacity.

The pathology indicates the percentage of unviable sperm to fertilize the egg, ie, the smaller the sperm, the greater the number of viable sperm for fertilization. Percentage of $12.5 \%$ and $31.5 \%$ for the breeder 1 and 2 respectively, were found. For goat species, values up to $20 \%$ of abnormalities are considered normal (HENRY; NEVES, 1998). Mieusset et al. (1992) reported that the increased sperm pathology in addition to interfering negatively with the ejaculate quality, it may affect the fertilizing power of the sperm or have serious consequences for embryonic survival. The color shown of both breeders was classified as yellow, where the assessment for this parameter is made visually and depends on the concentration of spermatozoa and possible presence of blood, pus, urine, skin cells and debris. The color is usually whitish, white, ivory or yellowish (HENRY; NEVES, 1998).

The waveform motion in a semen drop is called a whirlwind or mass movement, whose intensity is a result of motility, vigor and sperm concentration. The results for this parameter in the andrological evaluation were 4 to the younger breeder (1) and 1 for breeder 2 . Thus justifying the values found for this parameter being correlated with other parameters of vigor, motility and concentration in the andrological evaluation for both breeders.

Consequently, reproductive diagnosis (Table 4) comes to testify the andrological test results for breeders, where breeder 1 had higher pregnancy rate $(77 \%)$ than the breeder $2(46 \%)$, as well as the number of fetuses, 11 and 07 respectively.

The use of more than one study tool, as the observation of male' sexual behavior against the female in estrus, andrological evaluation and reproductive data, allows to diagnose more accurately the reproductive efficiency of male goat, becoming indispensable tools for selection of animals able to fulfill their reproductive activities. 
Table 4. Reproductive data regarding breeding season.

\begin{tabular}{cccc}
\hline \multirow{2}{*}{ Breeder 1 } & $\mathrm{N}^{\circ}$ of mated goats & Pregnancy $\%$ & Number of fetuses \\
\cline { 2 - 4 } Breeder 2 & 13 & 77 & 11 \\
& 13 & 46 & 7 \\
\hline
\end{tabular}

Breeder 1: aged at about 4 years; Breeder 2: aged at about 7 years.

Source: Elaboration of the authors.

\section{Conclusions}

Moxotó goat breeders of different ages showed intensity variation in the frequency of some behaviors during the stage prior the mating, which may reflect the percentages of mating and pregnancy, directly influencing the productivity indexes.

The courting with the paw, sound emission, tongue exposure, smelling the female's urogenital region, Flehmen reflex and penis exposure are part of the sequence of behaviors manifested by Moxotó goats during courtship of the female in estrus.

The breeder (age 4) has been classified as suitable for breeding, while the one aged seven was considered unsuitable from the andrological evaluation and reproductive data.

The study of behavioral patterns during the courting stage is an indispensable tool in predicting the reproductive potential of male goats; however, other aspects within the reproductive management should be evaluated in combination.

\section{References}

ALVES, D.; PEÑA-ALFARO, E. C.; LEITE, F. V. S.; NASCIMENTO, S. B.; SANTOS, F.C. B. Comportamento sexual de caprinos da raça Boer submetidos a regime intensivo de coleta de sêmen. Agropecuária Científica no Semiárido, Patos, v. 2, n. 1, p. 55-61, 2006.

BRITO, I. F.; ANDRIOLLI, A.; SANTOS, D. O.; BRITO, R. L. M.; RICARTE, A. R. F.; LIMA, F. M. S. Aspectos comparativos entre as raças Moxotó e Canindé quanto ao quadro espermático e a libido em sala de coleta de sêmen. In: ZOOTEC, 2008, João Pessoa. Anais... João Pessoa: Associação Brasileira de Zootecnia, 2008. p. 1-3.

CHEMINEAU, P. Medio ambiente y reproducción animal. 2004. Disponível em: <http://www. fao.org/ ag/Aga/AGAP/WAR/warall/v1650b/v16 50b04.htm>. Acesso em: 22 mar. 2010.

GOLDFREY, R. W.; COLLINS, J. R.; GRAY, M. L. Evaluation of sexual behaviour of hair sheep rams in a tropical environment. Journal of animal Science, Chicago, v. 76, n. 3, p. 714-717, 1998.

GORDON, I. Controlled reproduction in sheep and goats. In: Controlled reproduction in farm animal series. 2. ed. Wallingford-UK, 1999. p. 254-263.

HAFEZ, B.; HAFEZ, E. S. E. Reprodução animal. 7. ed. São Paulo: Editora Manole, 2004. 668 p.

HENRY, M.; NEVES, J. P. Manual para exame andrológico e avaliação de sêmen animal. 2. ed. Belo Horizonte: Colégio Brasileiro de Reprodução Animal, 1998. $49 \mathrm{p}$.

KUMAGAI, J.; FUKUDA, J.; KODAMA, H. Germ cellspecific shock protein 105 binds to $\mathrm{p} 53$ in a temperaturesensitive manner in rat testis. European Journal Biochemistry, v. 267, n. 2, p. 3073-3078, 2000.

LADEWIG, J.; PRICE, E. O.; HART, B. L. Flehmen in male goats: role in sexual Behaviour. Behavioral and nasal Biology, v. 30, n. 3, p. 312-322, 1980.

MCGARY, S. I.; ESTEVEZ, E.; RUSSEK-COHEN, E. Reproductive and aggressive behavior in male broiler breeders with varying fertility levels. Applied Animal Behaviour Science, v. 82, n. 1, p. 29-44, 2003.

MELVIN, J.; SWENSON, O. R.; WILLIAM, O. R. Fisiologia dos animais domésticos. 11. ed. Rio de Janeiro: Guanabara Koogan, 1996. 902 p.

MIES FILHO, A. Reprodução dos animais. 6. ed. Porto Alegre: Sulina, 1987. 58 p. 
MIEUSSET, R.; QUINTANA CASARES, P.; SANCHEZ PARTIDA, L. G.; SOWRBUTTS, S. F.; ZUPP, J. L.; SETCHELL, B. P. Effects of heating the testis and epididymites of ram by scrotal insulation on fertility and embryo mortality in ewes inseminated with frosen semen. Journal of Reproduction and Fertility, Cambridge, v. 94, n. 2, p. 337-344, 1992.

PACHECO, A.; QUIRINO, C. R. Comportamento sexual em ovinos. Revista Brasileira de Reprodução Animal, Belo horizonte, v. 34, n. 2, p. 87-97, 2010.

SALVADOR, D. F.; ANDRADE, V. J.; VALE FILHO, V. R. Desempenho reprodutivo de touros da raça Nelore, submetidos à classificação andrológica por pontos (CAP), à libido e desafiados com alto número de fêmeas com estro sincronizado. Revista Brasileira de Reprodução Animal, Belo horizonte, v. 25, n. 3, p. 185-187, 2001.

SALVIANO, M. B.; SOUZA, J. A. T. Avaliação andrológica e tecnologia do sêmen caprino. Revista Brasileira de Reprodução Animal, Belo horizonte, v. 32, n. 3, p. 159-167, 2008.

SALVIANO, M. B.; CAVALCANTE, T. V.; SOUZA J. A. T. Integrity of sperm DNA of native bucks agreed to scrotum conformation. Animal Reproduction, v. 3, n. 2, p. $252-259,2006$.
SANTOS, A. D. F.; TORRES, C. A. A.; FONSECA, J. F. Parâmetros reprodutivos de bodes submetidos ao manejo de fotoperíodo artificial. Revista Brasileira de Zootecnia, Viçosa, v. 35, n. 5, p. 1926-1933, 2006.

SANTOS, F. C. B.; ALFARO, C. E. P.; SOUZA, B. B. Influência da aptidão produtiva (leite ou carne) sobre a libido de bodes de raças exóticas e naturais da região semiárida do nordeste brasileiro. Ciência e Agrotecnologia, Lavras, v. 29, n. 3, p. 683-688, 2005.

STATISTICAL ANALYSIS SYSTEM INSTITUTE SAS. User's guide, version 8. SAS institute Inc., North Carolina, 1999. 295 p.

STELLFLUG, J. N.; LEWIS, G. S. Effect of early and late exposure to estrual ewes on ram sexual performance classifications. Animal Reproduction Science, v. 97, n. 3, p. 295-302, 2007.

TRALDI, A. S. Técnicas para otimizar o desempenho reprodutivo de cabras leiteiras. In: MATTOS, W. R. S. et al. A produção animal na visão dos brasileiros. Piracicaba: FEALQ, 2001. p. 474-483.

VERSTEGEN, J.; IGUER-OUADA, M.; ONCLIN, K. Computer assisted semen analyzers in andrology research and veterinary practice. Theriogenology, Philadelphia, v. 57, n. 2, p. 149-179, 2002. 